\title{
Investment Activity's Influence on the Rate of Differentiation of Regions' Social and Economic Development
}

\author{
Chernova T.V., Oleynikova I.N.* \\ Chair of Economics and Finance, Taganrog Institute for Management and Economics, Taganrog, 347900, Rostov region, Russia \\ Corresponding Author: i.olejnikova@tmei.ru
}

Copyright (C) 2013 Horizon Research Publishing All rights reserved.

\begin{abstract}
The strategic goal of national competitiveness requires efficient organization of a single economic space within the existing administrative-territorial entities. The regional investment activity of production and population living standards is estimated by the analytical group of statistical indicators. The analysis is confirmed by the direct link between investment activity and regional differentiation living standards indicators. The gross fixed capital formation perform status is determinant level of differentiation socio-economic regions, and the most important indicator is balanced financial result, which determines the formation of resources for efficiency integral investment. The regional investment policy is largely prioritized due to the source structure optimization.
\end{abstract}

Keywords Regional Investment Activity, Interregional Differentiation, Fixed Per Capita Asset Investments, Gross Fixed Capital, Financing Investment Sources, Preferential Tax Profits

\section{Introduction}

The effectiveness of functioning of Russian Federation's national economics like of any other state is the result of functioning of all residents who carry out their activity on the economic territory of the state. Mostly natural resources potential of the territory ascertained the direction of society development for a long time especially on the first stages of historical development of economic systems. As far as means and subjects of labor, and technical equipment improved, highly productive technology appeared, exchange processes of surplus product stirred to activity that dependence grew weak. However, nowadays in the age of globalization it doesn't disappear but consequently changes and complicates its forms. The stage of development less by existence of natural resources and more by scientific, technical, and intellectual potential; cultural and civilized orientation of society, its adaptation to global and regional trends; capability to produce knew knowledge, transform them into technical products, high quality goods and service is determined. Achievement of these strategic goals requires effective organization of the common economic area within the frameworks of present administrative and territorial units, transnational corporations, state structures, regional and interregional groups. Thereupon the goal of this article is to explore investment activity of the Russian Federation's regions as the fundamental factor forming interregional differentiation within the context of this factor's influence on parameters of effective development of national economics.

\section{Materials and Methods}

Despite all diversity of natural and other characteristics of any modern federative state its integrity, political and social stability depend on rate of regional unity of complex of social goods and ability of every region economics to provide them. A region is the basic territorial unit in the administrative structure of the present day Russia. Economical and social differentiation between regions-entities of the Federation is so much important to draw to itself increased attention. Ongoing growth of social and economic differentiation is stipulating the necessity to develop technology of territorial inequality research, and methodology of change of level of territorial differences to manage territorial asymmetry.

Set-off of the level of territories development one mostly explains by climatic conditions, natural resources, cultural features and all these are insufficient for carrying out the detailed analysis, despite they definitely play the role in the process of development but their influence is indirect and diverse. The specified factors can influence on the level of development cooperating with other factors such as social and demographic characteristics of population, technical and technological novelties, and efficient administration. Moreover the influence of the last factor can be of decisive importance. 
The existence of administrative borders of regions-entities of the Federation influences the level of their economic development, social, and cultural processes in the regions as they form peculiar barriers which hamper spatial interrelation between territories. Bodies of regional authority make decisions that influence either positive or negative on relations between regions population and their habitat that is a complicated correlation of economic, social, natural, legal and other components of the surroundings. On the score of that we can observe essential differences of living standards of population in regions that belong to one and the same nature-climatic zone, have sufficient bulk of physical and human capital and other similar positions of their economic potential. Answer to questions of leveling of social and economic development of regions lies in the system of coordinates of spatial economics; those questions determine growing trends of investment activity.

Structural change of the economics of Russia demands overwhelming investment resources that are necessary for rational investing to both industry and economics of regions - constituent territories of the Russian Federation taking into account the importance of regions development for the country. On the basis of elaboration of national priorities and formation of methods of adjustment of economics modernization appears the possibility of concentration of investment resources in the most significant directions. The example of the fast-developing Asian countries shows the evidence of necessity of strategic support of the state participation in priority projects. The successful realization of which depends on close mutual cooperation of the state and business. So in China every city that is significant for social and economic, and cultural development of the country has the state investment fund which by special state bank is managed, and main tasks of it are financing of infrastructure, energy, and transport projects, as well as granting credits for private business working on priority projects with foreign capital participation [1].

According to the worldwide experience economic growth mostly by flowing resources and capital from ineffective activities to profitable ones, and essential growing of regions' investment activities is stipulated. Apparently one can't wait significant economic growth of Russia while such factors are not activated. Virtually total denial from mechanisms of technical upgrading and renewal of industry under the circumstances of high level of wear and tear (at the mean in the country is $60 \%$ ) that is nowadays in the most areas of the real sector of economics is observed and it indicates the processes of deindustrialization also threats the existence of the most enterprises and economical stability of the national economics. According to opinions of several Russian experts the accumulated demand for changing obsolescent productive means will cost about 535 billion dollars.

To work out the efficient investment policy it is necessary to carry out complex and systematic analysis of investment activity of economic constituent territories. Such analysis will reflect direction and extent of rationality of investment recourses use from the different positions, among them are source of financing and patterns of ownership, structure of investing to fixed capital, dynamic aspect, interrelation with main summarized indices of efficiency of economic activity. Integrated economical and statistical investigation of investment activity includes detailed characteristics of separate aspects, revealing and assessing of its proper trends. Results of analytical work should be taken into account while taking into account management decisions as opportune and adequate respond on the existing circumstances of development of the country economics intensified by a worldwide financial crisis will allow to avoid unreasonable expenses and to increase economic effectiveness real sector of economics.

The key circumstance of effectiveness of the regional investment process is availability of investment resources which are essential for realization of significant investment projects; and they give the best return in economic and social spheres, and provide economical growth on the particular territory. It is important to find out what role plays the investment activity of economic entities on the constituent territory in the system of factors that influence the level of differentiation of social and economic state of regions.

Influence of regions' investment activity on production and population's living standard one can assess with the help of analytical classification of statistic data of the period of 2007-2011 and presented with simple average to obtain generalized characteristics of investigated events. Regional investments to the fixed capital per capita is the factor mark, and the gross regional product per capita and average money income per capita is the effective one. To form typological classification of regions-constituent territories of the federation by the level of their investment activity and to carry out further analytical calculation the data of the Federal Service of Statistics has been used [2].

Four groups of regions (Table 1) characterizing territorial features of formation investment activity of economic entities were pointed out as a result of data processing

The regions precisely singled out by the level of fixed per capita asset investments one can name respectively: low level of investment activity, middle level, high level and the very high one.

The first group includes constituent territories of the federation which normally specialize in areas of agriculture and adjacent spheres (food industry, leather works, textile industry, etc.) and have insufficient specific weight in the field of manufacturing activity.

The second group includes the greatest number of regions which mainly specialize in the field of manufacturing activities, mining operations, producing and distribution of electric power; they have advanced traffic centers, and well-developed logistic infrastructure.

In contrast with the second group in the economic entities of regions of the third and the fourth groups orient towards different types of economic production of competitive products of export purpose and propose financial services. 
Table 1. Classification of regions according to the rate of investment in fixed capital per capita

\begin{tabular}{|c|c|c|}
\hline Group number & $\begin{array}{l}\text { Investment in fixed capital per capita, } \\
\text { Thousands Russian Rubles. }\end{array}$ & Group composition \\
\hline 1 & $\begin{array}{l}\text { Up to } 30,0 \\
\text { Low level }\end{array}$ & $\begin{array}{l}\text { Altay, Stavropol, Bryansk, Ivanovo, Kostroma, Kurgan, Oryol, } \\
\text { Volgograd, Kirov, Saratov, Pskov regions; Tyva, Buryatiya, } \\
\text { Ingushetiya, Kabardino-Balkaria, Karachay-Cherkessia, North } \\
\begin{array}{l}\text { Ossetia-Alania, Adygeya, Kalmyk, Mariy-El, Khakasia } \\
\text { republics. }\end{array}\end{array}$ \\
\hline 2 & $\begin{array}{c}30,0-60,0 \\
\text { Middle level }\end{array}$ & $\begin{array}{l}\text { Krasnodar, Trans-Baikal, Kamchatka, Primorskiy, Khabarovsk, } \\
\text { Kursk, Smolensk, Tver, Novgorod, Nizhniy Novgorod, } \\
\text { Sverdlovsk, Vladimir, Kaluga, Yaroslavl, Ryazan, Belgorod, } \\
\text { Voronezh, Tula, Tambov, Vologda, Murmansk, Rostov, } \\
\text { Orenburg, Penza, Samara, Ulyanovsk, Astrakhan, Chelyabinsk, } \\
\text { Kemerovo, Novosibirsk, Omsk, Irkutsk regions; Karelia, } \\
\text { Dagestan, Bashkiria, Chechen, Mordovia, Udmurt, Chuvash, } \\
\text { Altay republics; Jewish autonomous region. }\end{array}$ \\
\hline 3 & $\begin{array}{l}60,0-90,0 \\
\text { High level }\end{array}$ & $\begin{array}{l}\text { Lipetsk, Moscow, Arkhangelsk, Kaliningrad, Tomsk, Amur, } \\
\text { Magadan regions; Tatarstan, Komi republics; Moscow, } \\
\text { Saint-Petersburg. }\end{array}$ \\
\hline 4 & $\begin{array}{l}90,0 \text { and over } \\
\text { Very high level }\end{array}$ & $\begin{array}{l}\text { Leningrad, Tyumen, Sakhalin regions; Sakha republic, } \\
\text { Chukotka autonomous district. }\end{array}$ \\
\hline
\end{tabular}

Table 2. Influence of investment activity in regions on rates of living standard

\begin{tabular}{|c|c|c|c|c|c|c|c|c|}
\hline No & $\begin{array}{c}\text { Classification interval, } \\
\text { Thousands Rubles. }\end{array}$ & Number of regions & FPCAI, Rub. & $\begin{array}{c}\mathrm{K} \sigma \\
\%\end{array}$ & $\begin{array}{l}\text { GRPPC, } \\
\text { Rub. }\end{array}$ & $\begin{array}{c}\mathrm{K} \sigma \\
\%\end{array}$ & $\begin{array}{l}\text { AMIPC, } \\
\text { Rub. }\end{array}$ & $\begin{array}{c}\mathrm{K} \sigma, \\
\%\end{array}$ \\
\hline 1 & Up to 30,0 & 21 & 23008 & 23,5 & 90872 & 26,6 & 8878 & 17,0 \\
\hline 2 & $30,0-60,0$ & 42 & 41573 & 20,3 & 145025 & 28,9 & 11824 & 23,0 \\
\hline 3 & $60,0-90,0$ & 11 & 72902 & 13,7 & 264023 & 48,3 & 16814 & 40,0 \\
\hline 4 & 90,0 and over & 5 & 202920 & 29,0 & 498258 & 37,3 & 22419 & 29,3 \\
\hline
\end{tabular}

Analytical classification (Table 2) on the basis of singled out types of regions according to their level of investment activity allowed to determine the dependence between the average rate of fixed per capita asset investments (FPCAI) and the average rates of living standards indices in these regions (gross regional product per capita (GRPPC)) and the average money income per capita of a region's population (AMIPC).Obtained results confirm existence of stable direct relation between regions' investment activity and rates of differentiation of population's living standard. Coefficients of variation characterize the rate of objectivity of carried out classification and representativeness of calculated means of features under investigation nearly of all groups. High level of variation in the third group according to gross regional product data and rate of money incomes indicates peculiar problems in effectiveness and market selectivity in usage of data on investment resources in different regions. For instance the third group according to rate of investments contains the federative region of Moscow city and the great bulk of GRP per capita $(722,5$ thousand Rubles) first of all by its status is stipulated, and Amur region has the rate of investments higher than average in this group (81,3 thousand Rubles) but the return from the investments as the increasing of gross regional product much more lower than of any constituent territories of this group have. Low return by investing to nonmaterial sphere can be explain or gross fixed capital formation take place for obtaining new profit in the future.

Gross fixed capital formation in the constituent territories of the Russian Federation determines investment activity of constituent territories and it is the determinant of level of differentiation of regions' social and economic status, this determinant by generalized data of productive and economic activity of every economic entity of the region is characterized. Balanced financial result (profit minus loss) is the most integral index that shows effectiveness of productivity of the whole economics of the region. Financial state of organizations; possibility to fulfill obligations on payments to budget, to suppliers for factory shipment, and other creditors; and also formation of resources for investment activity depend from the rate of obtained balanced financial result. Values of correlation coefficient $\boldsymbol{r}$ are calculated taking into account average data in the Federal Districts (macroregions) of the Russian Federation in the analyzed period of time [2]:

$$
r=\sum\left(x_{i}-\bar{x}\right)\left(y_{i}-\bar{y}\right) / n \sigma(x) \sigma(y)
$$

confirm close coherence between rates of gross fixed capital $(y)$ and the rate of balanced financial result $(x)$ (Table 3). 
Table 3. Values of correlation coefficient in the Federal Districts

\begin{tabular}{|c|c|c|c|c|c|c|c|c|}
\hline FD & CFD & NWFD & SFD & VFD & UFD & SibFD & FEFD & RF \\
\hline $\mathrm{r}$ & 0,872 & 0,831 & 0,895 & 0,919 & 0,916 & 0,925 & 0,763 & 0,964 \\
\hline
\end{tabular}

Table 4. Correlation of own $(\mathrm{O})$ and borrowed $(\mathrm{B})$ funds in source of financing investments to the fixed capital in the Federal Districts in 2000-2010*Federal district

\begin{tabular}{|c|c|c|c|c|c|c|}
\hline & \multicolumn{2}{|c|}{2000} & \multicolumn{2}{|c|}{2005} & \multicolumn{2}{|c|}{2010} \\
\hline & $\mathrm{O}$ & B & $\mathrm{O}$ & B & $\mathrm{O}$ & B \\
\hline CFD & 33,6 & 66,6 & 38,2 & 61,8 & 35,3 & 64,7 \\
\hline NWFD & 48,2 & 51,8 & 42,9 & 57,1 & 30,0 & 70,0 \\
\hline SFD & 34,6 & 65,4 & 40,8 & 59,2 & 32,5 & 67,5 \\
\hline VFD & 60,1 & 39,9 & 49,9 & 50,1 & 45,3 & 54,7 \\
\hline UFD & 52,0 & 48,0 & 55,3 & 44,7 & 50,9 & 49,1 \\
\hline SibFD & 64,9 & 35,1 & 55,3 & 44,7 & 55,5 & 45,5 \\
\hline FEFD & 52,4 & 47,6 & 24,3 & 75,7 & 25,9 & 74,1 \\
\hline $\mathrm{RF}$ & 47,5 & 52,2 & 44,5 & 55,5 & 37,8 & 62,2 \\
\hline
\end{tabular}

* composed based on data [2]

Calculation show that coherence between features under investigation in the regions of the Siberian Federal District is stronger, and the weakest coherence is in the regions of the Far East Federal District. The rates of the balanced financial result considerably influence on financing investment sources. Financing investment sources to fixed capital are:

- Equity of company which first of all includes capital charges and profit that remains at a company's disposal. Out of proceeds that is used for accumulation industrial and scientific development is carried out, assets (buying capital issues) is formed, investment to authorized capital stock of other companies is contributed, etc.;

- Borrowed funds including funds of federal and local budgets, bank credits, borrowed funds of other companies, non-budget funds, funds obtained by shares issue.

Foreign investments plays important role in activation of investment processes in regional economics. Dynamics of coherence of internal funds and borrowed funds in financing investment sources to fixed capitals of macroregions in the Table 4 is presented.

The data in the table shows that main financing investment source in the Federal Districts in 2000 was internal funds, however in the period of 2000-2005 the situation changed in favor of borrowed funds, and since 2005 virtually in all macroregion the increasing of use of borrowed funds is observed.

In accordance with considering dynamics of change of correlation between internal and borrowed funds one can point out further trends. First, there are regions where stable dominance of internal financing investment sources stays constant (Urals FD) or it decreases insufficiently (Volga
FD). Second, there are regions where the observed dynamics shows essential decrease of internal funds and therefore considerable growth of borrowed funds takes place (North-West, Far East, and Siberian Federal Districts). The third group consists of regions of Central and Southern Federal Districts in which dynamics of existing correlation of internal and borrowed funds virtually doesn't change; in these regions the borrowed funds are the main source of financing investments to the fixed capital. Generally internal funds of companies prevail over sources of borrowed funds in the economically well developed regions because large industrial enterprises and companies which produce competitive and intended for export types of goods successfully function on their territory. Investments to the fixed capital are the circumstances of profit growth as improvement of manufacture by upgrading and modernization of equipment, elaboration and use of innovative technologies allow producing greater bulk of competitive production. It is preferable to use internal source of financing because they possess quite high return as the rate of profit from invested capital is higher because one needn't pay for borrowed external sources, also the risk of disability and bankruptcy of an enterprise decrease in view of absence of trade liabilities. Moreover capital charges as internal source of financing investments at any financial state of an enterprise is formed and stays at its disposal forever.

However the present day state of economics leaves much to be desired and much of industrial enterprises functions on the verge of existence and consequently profit plays insufficient role in financing of capital investment so the considerable part of capital charges is used improperly. Two sources of financial investment that belong to borrowed funds draw to themselves special attention in such 
kind of situation; they are bank loans and assets from the federal budget.

The loan is the most important integrating instrument of formation, distribution, and use of investment resources on all levels of economic entities. The bank loans as the mean of investment through the analyzed period usually by regions of the Central, North-West, and Siberian Federal Districts has been used, this is by high investment attractiveness of iron and steel works in the Lipetsk region, oil production in the Komi Republic, gold mines in Khakasia is explained. The Tatarstan, Mariy El, Udmurt republics of the Volga Federal District, the Sverdlovsk region of the Ural Federal District, Khabarovsk region of the Far East Federal District had the great share of the bank loans in borrowed funds. The share of the bank loans of the major economic centers (Moscow and Saint-Petersburg) is extremely insufficient, and this is despite high level of banking infrastructure development of these constituent territories of the Federation.

Russia experiences distribution of different forms of the federal investment support of regions lately. Unevenness in distribution of funds from the federal budget inside of the Federal Districts is quite high this by intention of the federal center to reduce a gap in the level of social and economic development of regions is caused. Attraction of comparatively high share of funds from the federal budget is typical for the regions of the Northern Caucasus, several territories of the Far East and Siberian Federal Districts; these regions have extremely low investment attractiveness for private investors.

The increasing of rate of borrowed fund in financing investments from the one hand raises the level of their mobilization and allows carrying out the investment activity in short terms. From the other hand it demands providing credit security with property, increase the risk of bankruptcy owing to late return of borrowed funds, and leads to loss of some profit from investment activity because of interest payments for the use of borrowed funds. All these bring threats of lowering growth rate of the regional economics.

Structural distribution of foreign investments in the federal districts is extremely uneven. Over $60 \%$ of direct foreign investments goes to Moscow and the Moscow region, $10 \%$ goes to the Krasnoyarsk region it attracts investors with the Krasnoyarsk Aluminum Works and "Norilskiy Nickel"; these enterprises specialize on mining natural resources. In the rest regions the share of foreign investments is quite low; and this is determined solely by corresponding level of investment attractiveness of every region, characteristics of investment climate that is favorable to stable development of regional economics. In the system of factors influencing the level of differentiation of regional development foreign investments as essentially increasing the rate of inequality are considered. Therefore regional and local authorities should form their investment policy keeping in mind the developing of favorable investment climate.

\section{Conclusion}

To provide stable economic growth of the region it is necessary to form optimum relationship of internal and borrowed funds in the sources of investment financing to fixed capital; the relationship should correlate to financial strategy of enterprises, and should not decrease the level of their financial stability. The main criteria for structure optimization of sources of investment activity financing is maximization of the sum of profit obtained from investment activity that remains at enterprise's disposal and providing high financial stability of the activity. Regional investment policy plays important role, it solves tasks on building infrastructure of the investment market, determine priority directions of investment, support investments of the local authorities, form favorable investment climate. Regional investment policy is closely related to investment policy of the state. It occupies dominating position and the position shows that the regional investment policy establishes "rules of the game" in the sphere of investments, first of all, by improvement system of taxation and establishing special tax treatment for entities involved into investment activity.

In every overdeveloped country the differentiated system of tax concessions is applied, the main purpose of which on stimulating of investments is directed. In the Russian Federation the preferential tax profit also was used, but nowadays they are cancelled, and this significantly decreases the investment activity of economic players. The restoration of the system of preferable tax profit for enterprises that carry out investment activity which is directed towards increasing of productivity and labor quality will provide retention of path economic growth of regional economics as well as additional dynamics to positive changes in national economic development.

\section{REFERENCES}

[1] Paul Fisher. Rossiya i mirovye pritoki pryamykh inostrannykh investitsiy: problemy i perspectivy, Voprosy statistiki, No. 9, 2005.

[2] Regiony Rossii. Sotsialno-ekonokicheskie pokazateli. 2011: Stat.sb. M.: Rosstat, 2011.

[3] Resursnyy potentsial ekonomicheskogo rosta: Nauchnoe izdanie / Pod red. M.A. Komarova. M.: Ekonomicheskaya literatura, 2002.

[4] Chitaya G.O. Istochniki investitsionnogo obespecheniya ekonomicheskogo razvitiya makroregionov Rossii, Voprosy statistiki, №9, 2005. 